\title{
Potential of jet biofuels production and application in
} Ukraine and Poland

\author{
Anna lakovlieva* \\ Ecology Department, \\ National Aviation University, \\ Kyiv, Ukraine \\ Email: pinchuk_anya@ukr.net \\ *Corresponding author
}

\section{Sergii Boichenko}

Department of Internal Combustion Engines and Transport, Rzeszowska Politechnika,

Rzeszow, Poland

Email: chemmotology@ukr.net

\section{Oksana Vovk}

Ecology Department, National Aviation University, Kyiv, Ukraine

Email: o.a.vovk@mail.ru

\section{Kazimierz Lejda}

Department of Internal Combustion Engines and Transport, Rzeszowska Politechnika, Rzeszow, Poland

Email: klejda@prz.edu.pl

\begin{abstract}
The present-day situation in civil aviation is discussed. Taking into account limitation of crude oil resources for jet fuel production and worsening of the ecological situation, the tendency to transition to alternative fuels is presented. The perspectives of Ukraine and Poland in production and application of alternative jet fuels is figured out. Main attention is paid to reveal possibilities of these countries for production of jet biofuels derived from plant oils. The potential of biofuels production from various feedstocks is presented and analysed. The advantages of oil-derived biofuels production and application are discussed.
\end{abstract}

Keywords: jet fuel; alternative fuel; harmful emission; environment; plant oil; aviation biofuel; aircraft; Ukraine; Poland.

Reference to this paper should be made as follows: Iakovlieva, A., Boichenko, S., Vovk, O. and Lejda, K. (2015) 'Potential of jet biofuels production and application in Ukraine and Poland', Int. J. Sustainable Aviation, Vol. 1, No. 4, pp.314-323. 
Biographical notes: Anna Iakovlieva received her MSc in Ecology at the National Aviation University. She has finished her post-graduate studies and preparing her PhD thesis. She is an assistant of the Ecology Department at the National Aviation University and a Junior Scientific Researcher. Her sphere of scientific interests - aviation chemmotology, alternative jet fuels and environmental protection. She has published more than 25 papers in Ukrainian and international scientific journals.

Sergii Boichenko is Doctor of Sciences, Professor of the Department of Internal Combustion Engines and Transport at Rzeszowska Politechnika, and Professor of the Ecology Department at the National Aviation University. He is a Director of the Ukrainian Research and Educational Center of Chemmotology and Certification of Fuels, Lubricants and Technical Liquids. His sphere of scientific interests: effective and rational use of fuels, lubricants and technical liquids, and environmental protection. $\mathrm{He}$ is an author of more than 200 scientific papers in Ukrainian and foreign scientific journals.

Oksana Vovk has finished her Doctor thesis at the National Technical University of Ukraine 'Kyiv Polytechnic Institute' and now she is a Doctor of Sciences, Professor of the Engineering Ecology Department at the National Technical University of Ukraine 'Kyiv Polytechnic Institute' and Professor of the Ecology Department at the National Aviation University. Her scientific interests are sustainable development, energy safety and environmental protection. She has published more than 100 papers in Ukrainian and international scientific journals.

Kazimierz Lejda received his $\mathrm{PhD}$ degree at the Cracow University of Technology and his doctor degree at the Kyiv Institute of Transport and Roads. $\mathrm{He}$ is a Doctor of Sciences, Professor of the Department of Internal Combustion Engines and Transport at Rzeszowska Politechnika. His scientific interests are: systems and means of motor transport, internal combustion engines, effective and rational use of fuels. He is an author of more than 300 scientific papers in foreign scientific journals.

This paper is a revised and expanded version of a paper entitled 'Potential of jet biofuels production and application in Ukraine and Poland' presented at International Symposium on Sustainable Aviation (ISSA-2015), Istanbul, Turkey, 31 May-3 June 2015.

\section{Introduction}

Today, application of alternative energy sources in various spheres of human activity becomes more and more popular all over the world and in Eastern European countries as well. Along with development and implementation of alternative motor fuels, scientists around the world study perspectives of partial or total substitution of traditional jet fuels with their alternative analogues. Following the world tendencies, we see the need to consider potential in development and application of alternative jet fuels in such countries as Ukraine and Poland. 


\section{Literature overview}

Modern civil aviation is developing constantly. The world volume of aircraft transportation increases by $4 \%$ to $5 \%$ annually. As a result during the last decade consumption of fuels for air-jet engines has increased by $21 \%$. As it is stated in Iakovlieva and Boichenko (2012a) about 5.5 thousand barrels of jet fuel are produced and consumed in the world daily. The statistics of jet fuels consumption in Ukraine and Poland are shown in Figure 1.

Figure 1 Statistics of jet fuel consumption in Poland and Ukraine (see online version for colours)

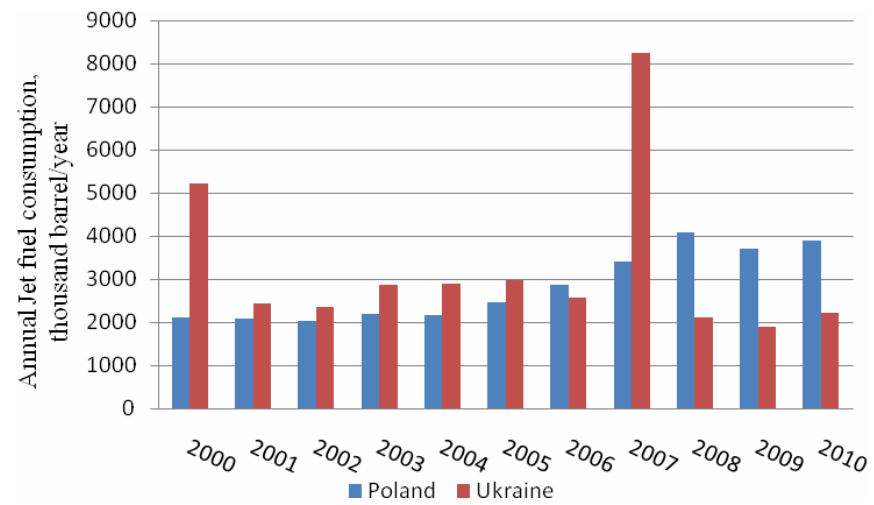

Thus, today aviation is one of the most significant consumers of oil-derived jet fuels. Oil and other fossil fuels used for production of both jet and other kinds of fuels are exhausted irreversibly. Oil deposits are estimated at about 40 years, natural gas -70 and coal -230 years. $\mathrm{CO}_{2}$ emissions accompanying processes of fuel production and use, lead to increased greenhouse effect, and therefore global warming (Hemighaus et al., 2006). Intergovernmental Panel on Climate Change and International Energy Agency (IEA) state that modern aviation is a source of about $2 \%$ of the world's total $\mathrm{CO}_{2}$ emissions. Besides $\mathrm{CO}_{2}$ aircraft exhaust gases contain a number of other components that negatively influence on the state of environment: $\mathrm{SO}_{\mathrm{x}}, \mathrm{NO}_{\mathrm{x}}, \mathrm{CO}, \mathrm{CH}_{4}$, soot, and others (Iakovlieva and Boichenko, 2012a).

This situation promoted strengthening of ecological requirements to quality of jet fuels. A number of influential organisations took measures to reduce the aviation negative impact on environment (Bauen et al., 2009). International Air Transport Association (IATA) has set up a task force to reduce the level of $\mathrm{CO}_{2}$ emissions from air transport by $50 \%$ by 2050 . In addition, European Commission in 2011 has set a policy target of achieving a $60 \%$ reduction of $\mathrm{CO}_{2}$ by 2050 . Low-carbon fuels in aviation should reach $40 \%$ by 2050 .

\section{Modern situation in sphere of jet fuels production}

Traditionally, fuels for jet engines are produced from crude oil, coal, natural gas, oil sands and oil-shales. However, technologies are quite energy-intensive and difficult for realisation. Limitation of the world's oil deposits and other fossil fuels promotes 
development of alternative technologies for jet fuels production. Today, numbers of organisations pay much attention to investigation of existing and newly appeared technologies for alternative jet fuels production. Scientists define jet fuels derived from: conventional oil, unconventional oil (oil sands and oil shale), natural gas, coal, or biomass via the FT-process, renewable oils (biodiesel, biokerosene, hydroprocessed renewable jet or hydrotreated vegetable oil - HVO) and alcohols (ethanol and buthanol). However, alcohol-derived fuels are suitable for aviation piston engines only (Hemighaus et al., 2006). The best prospects are fuels derived from plant feedstock - the so called biofuels. IEA forecasts the share of biofuels in total balance of fuel in transport sector will reach $4 \%$ to $6 \%$ by 2030 .

When discussing the state of biofuels production in Ukraine, it should be mentioned that level of biofuels branch development is significantly lower than in EU countries. According to Kaletnik (2008), the total supply of primary energy sources in Ukraine is more than $130 \mathrm{M}$ ton of oil equivalent, but amount of biofuel is just $1.48 \mathrm{M}$ ton that is $1.13 \%$ in structure of energy supply. At the same time in EU countries this index reaches $6.72 \%$. The total supply of primary energy in EU countries is estimated at $1,759 \mathrm{M}$ ton of oil equivalent with the share of biofuels of $118 \mathrm{M}$ ton [Figure 2(a) to Figure 2(c)] (Kondili and Kaldellis, 2007).

Figure 2 Share of biofuels in structure of energy supply, (a) in EU countries (b) in Poland (c) in Ukraine (see online version for colours)

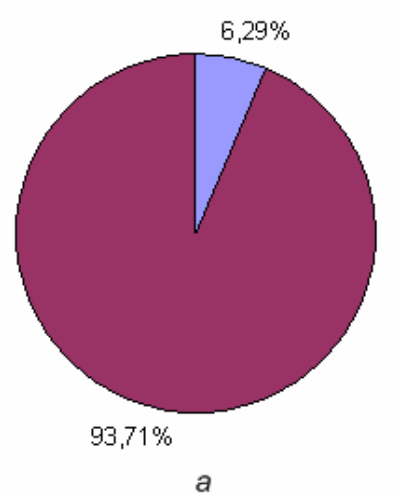

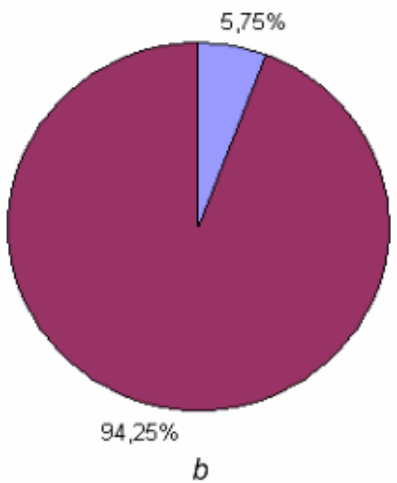

$\square$ Traditional energy sources $\square$ Biofuels

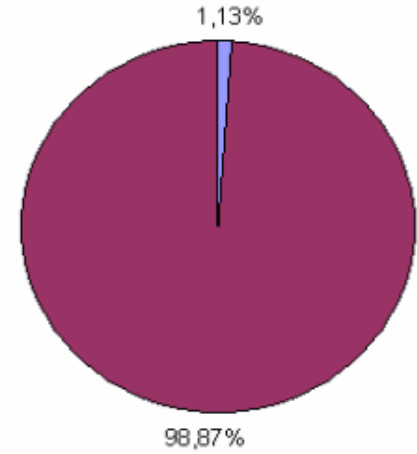

c

\section{State and perspectives of jet biofuel production in Ukraine and Poland}

Poland and Ukraine as well as other European states are characterised by deficiency of oil deposits. Ukraine consumes about $130 \mathrm{M}$ ton of fuel-energy resources annually, satisfying its need in energy resources on around $53 \%$. In order to satisfy needs of civil aviation Ukraine requires about 400,000 ton of aviation kerosene. At the same time sphere of jet fuels production is characterised by opposite situation. Production of aviation kerosene at Ukrainian enterprises in 2011 decreased by $16.6 \%$ comparing to previous year, which is up to 282,000 ton. The final energy consumption for 
transportation purposes in Poland in 2005 was 10.27 million ton of energy equivalent (Mtoe).

Generalising the world's experience in alternative jet fuels development we have concluded that the optimal kind of aviation biofuel is biokerosene, which is derived from renewable oils (Iakovlieva and Boichenko, 2012b). The technology of biokerosene manufacturing seemed to be the most rational for both Ukrainian and Polish conditions. This kind of biofuel is obtained via processing of oil plants. Biokerosene is a mixture of traditional kerosene, produced from crude oil, and biocomponents in certain concentrations. The percentage of biocomponent can reach 50\%. Advantages are explained by availability of feedstock, maturity of technology, presence of necessary equipment, satisfactory physical-chemical and exploitation properties of such kind of biofuel and also its ecological safety.

\section{Feedstock base for jet biofuels production}

Feedstock for biocomponents production is oils, obtained from seeds of various agricultural oily plants: rape, sunflower, camellina, jatropha, canola, palm oil, etc. The main factor for feedstock selection is surely geographical and climatic conditions typical for country-producer and optimal for certain oily plant cultivation (Devianin et al., 2007) Base of European biofuel industry is rape and during last years - camellina. Ukraine and Poland are traditionally agricultural countries with well-developed oil production branch (Proskurina, 2011; Pietak and Radkowski, 2011). Hence they have a great potential for development of jet biofuels manufacturing. The most typical oil cultures in Ukraine are sunflower, rape, soy; camellina and corn are less popular (Figure 3).

Figure 3 Production of main oily plants in Ukraine in 2012 (thousand ton) (see online version for colours)

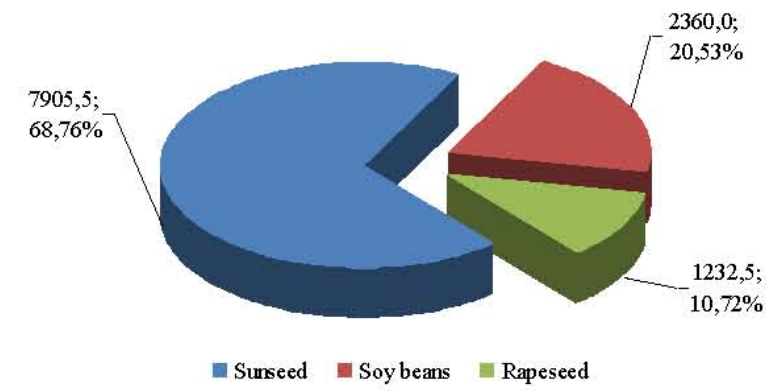

Owing to the large area of agricultural terrains, Poland has a great potential to use renewable energy. The main renewable energy source in Poland is biomass. Today Poland is one of the most promising countries in EU concerning biofuel feedstock production. The most typical oil cultures in Poland are sunflower and rape (Figure 4) (Pietak et al., 2011). Such plants as soy, camellina, etc., are still not cultivated in industrial scales. However, comparing to Ukraine, only rape oil is considered to be used as a feedstock for biofuels production. 
Figure 4 Production of main oily plants in Poland in 2014 (thousand ton) (see online version for colours)

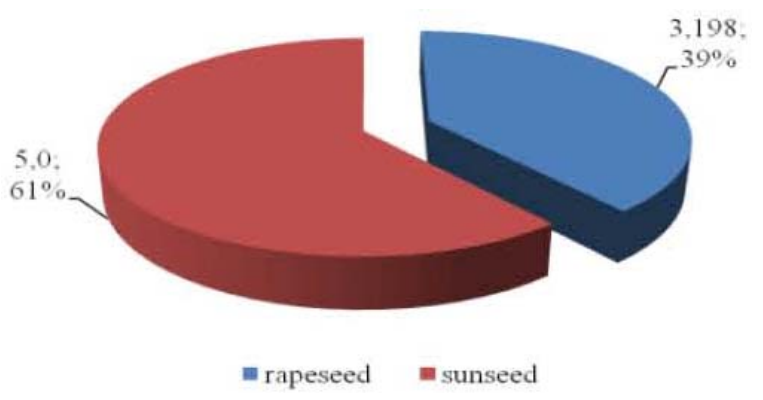

Sunflower is the main oily plant cultivated in Ukraine. Its part in the total yield is about $70 \%$. Seeds of ordinary varieties contain $50 \%-52 \%$ of oil, while selected varieties contain up to $60 \%$. Comparing to other oily plants, sunflower allows production of quite high volume of oil - 952 1/ha ( 890 - 1/ha on average in Ukraine). Recent years are characterised by significant growth of sunflower production (Proskurina, 2011). Today, sunflower productivity is about $1,840 \mathrm{~kg}$ per ha, that is much higher than in 2002-2004 (about 1,100-1,300 kg per ha). Most sunflower oil is used for food industry, production of high-protein forage, oil meal and other technical needs, thus it is not rational to consider sunflower as a feedstock for biofuel industry.

Another oily plant, rape is being cultivated in Ukraine in industrial volumes only during last eight to ten years. This is explained by strong world's demand for rape oil for biofuels production. Rapeseeds contain $45 \%-50 \%$ of oil, $24 \%-31 \%$ of proteins and $6 \%-12 \%$ of fibre. According to Dubel (2010), today the productivity of rape is about $1,500-1,700 \mathrm{~kg}$ per ha, and can reach up to $2,400 \mathrm{~kg}$ per ha. Average yield of rape oil is around 1,190 1/ha. Certain rape varieties with low content of erucic acid have been already selected; that is a positive factor for production of biofuels. Several years ago rape was cultivated in Ukraine with the aim of export only. Its internal processing was almost absent and did not exceed 10\%. However, now a significant increase in volumes of internal processing is observed (Figure 5).

Figure 5 Statistics of rape production in Ukraine and its share in total volume of oily plants cultivation (thousand ton) (see online version for colours)

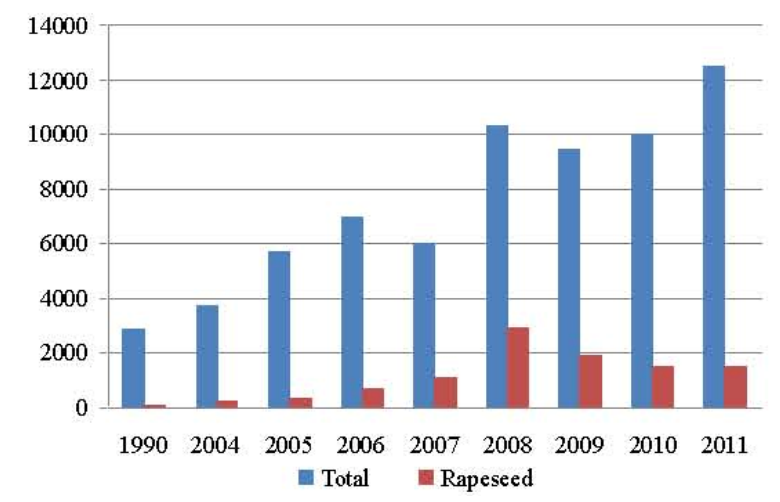


Comparing to rape, during recent years high rates of soy production are observed in Ukraine. Soy average fertility is about $1,500-2,000 \mathrm{~kg}$ per ha with comparatively low oil yield - 446 1/ha (Proskurina, 2011; Dubel, 2010). Content of oil in soy seeds is about $16 \%$ to $27 \%$. Soy oil is characterised by high content of unsaturated fatty acids (86\%-87\%); this makes a certain impact on its physical-chemical properties. At the same time it contains $40 \%-50 \%$ of high-quality proteins (Kondili and Kaldellis, 2007). Hence soy culture is widely used for production of food oil, protein concentrates and various food products. It should be mentioned that soy production requires significant resources and material-technical base for its cultivation.

Today, camellina is cultivated on some territories of North-West and Central Europe and not for a long time in Ukraine. Camellina is easily grown on unfertile soils, undemanding to external conditions, resistant to low temperatures and dry weather. Plant has short vegetating period; this allows growing other cultures after harvesting camellina. When grows naturally its yield is 1,000-1,200 $\mathrm{kg}$ per ha on average and can reach 2,000 and even 3,000 kg per ha. Camellina seeds contain $40 \%-50 \%$ of oil and oil yield is about $1,250 \mathrm{l} / \mathrm{ha}$. During recent years application of camellina oil as a feedstock for biofuels production is highly popular. In Ukraine, camellina oil production is still developing. This culture is technical, so biofuel production will not compete with food industry. In Poland, camellina is still not considered as a biofuel feedstock. Taking into account world and European tendencies in particular, we may predict that camellina production in Poland and Ukraine will be increasing rapidly (Proskurina, 2011; Kaletnik, 2008).

Figure 6 Production and consumption of rape oil derived biofuels in Poland (see online version for colours)

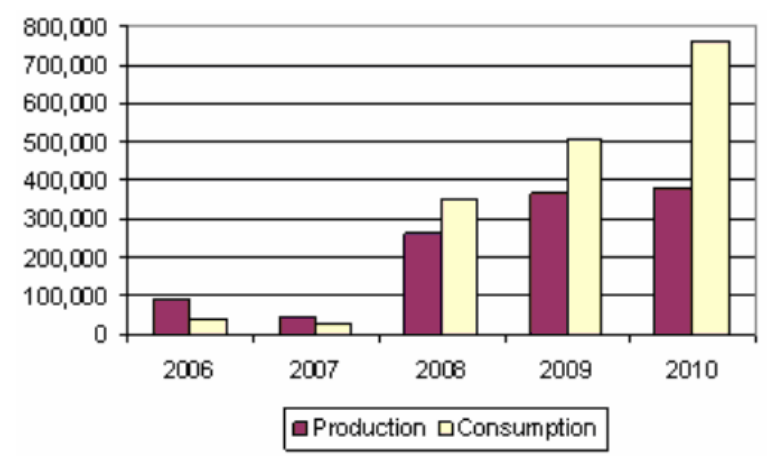

During recent years, Poland has become one of the leading countries within the EU, with regard to biofuels production. Today Poland is treated as one of the main rapeseed producing countries (Wisniewski et al., 2005). As a result, the new capacities in the country are being installed, mainly encouraged by the incipient growth of domestic consumption. The biofuels sector in Poland is mainly driven by the European incentives and directives aiming at considerably increasing biofuels production and use. Along with other European states according to recent European regulations, the mandatory target for 2020 has been set at a minimum level of $10 \%$ biofuel component in transportation fuels in Poland. Considering the Poland case the potential of rape cultivation should be determined. More specifically, in Poland, the production of rapeseed increased sharply from 0.7 in 2003 to $1.25 \mathrm{M}$ tons in 2004 (Pietak and Radkowski, 2011). In recent years, 
an increasing trend in biofuels production and consumption can be seen (Figure 6). In 2011, in Poland there were registered 20 producers of biofuels made of rape oil (Królczyk et al., 2014).

\section{Technology of jet biofuel production}

Oils derived from the mentioned above plants have different physical-chemical properties, however these differences are not significant. At the same time they differ from properties of fuels for air jet engines. That is why it is rational to use products of oils processing - ethyl and methyl ethers. Owing to its chemical composition biofuel is characterised by high lubricating properties; this allows increasing of aircraft details lifespan. Moreover, application of biofuel produced according to the mentioned technology does not require additional re-equipment or modernisation of engines and their systems. Exclusively low sulphur content in biofuels due to its natural origin may allow significant decreasing of toxicity of aircraft exhaust gases, thus minimising negative impact on environment. Another quite important factor that determines interest to jet biofuels is its ability to be decomposed easily in natural environment without doing harm to living objects (Iakovlieva et al., 2013).

Technology of ethyl (methyl) esters production is quite simple and similar to process of biodiesel manufacturing. The process is based on the reaction of esterification of fatty acids contained in plant oils using methanol or ethanol and basic catalyst (Figure 7). In a result of this process esters of plant oil and glycerine are obtained (Sagar et al., 2011). After that esters of fatty acids undergo vacuum distillation, provides better level of ester purification (Iakovlieva et al., 2014). This allows using them as components of jet fuels.

Figure 7 Chemical reaction of plant oils esterification

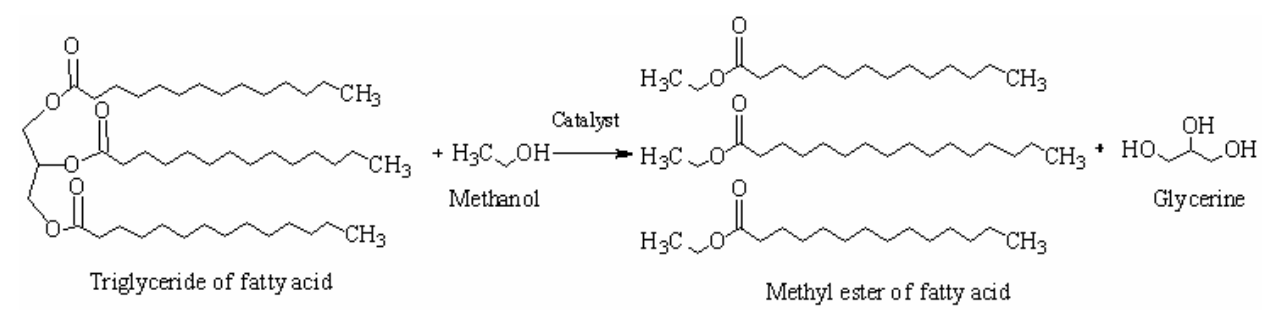

Today, the technology of biofuel production is realised successfully both in laboratories and industrial enterprises. Taking into account experience of European countries, biofuel manufacturing in Ukraine can be organised at the low-tonnage installations (local level for certain enterprises) with productivity 300-3,000 ton/year, regional factories, producing 10,000-30,000 ton/year and large-scale industrial factories (Iakovlieva and Boichenko, 2012b). Technological process of jet biofuel production from plant oils is significantly simpler than crude oil refining and profitability of the process is two-three times higher. Also, plant feedstock is a renewable resource and thus it is comparatively unlimited. 


\section{Conclusions}

In general Ukraine and Poland among other countries have considerable resource potential for jet biofuel production from plant oils. The main advantage of feedstock cultivation in Poland is a presence of high level of governmental support to biofuel producing industry that is based on European biofuel implementation programs. However, Poland's potential in biofuel feedstock production is not realised completely. Today, only rapeseed is cultivated for providing feedstock for biofuels production; at the same time the biofuel potential of sunflower, soy and camellina oils is not realised. On the contrary with no or almost absent governmental support Ukrainian producers develop oil production from traditional oily plants for satisfying biofuel industry needs. Being one of the leading countries in Europe by volumes of rape and sunflower production Ukraine is still one of the top rapeseed exporters to EU. At the same time Ukrainian oil producers promote growing of new biofuel cultures, such as camellina, soy and some others. These countries have all possibilities for jet biofuel manufacturing for its own needs and for export also.

Implementation of biofuels derived from plant feedstock surely has potential and prospects for its future development. Application of biofuels should be totally in the scope of sustainable development principles and does not do harm to food industry. In future application of alternative jet fuels will have the following positive results: availability of feedstock that is important for countries that do not possess their own deposits of fossil fuels; saving of exhaustible energy resources; decreasing volumes and toxicity of aircraft exhaust gases, thus protecting air quality in lower atmosphere layers; comparative simplicity and low cost of biofuel production process; low price for biofuel comparing to traditional kerosene; stimulation of agricultural complex development in countries that produce biofuels.

\section{References}

Bauen, A., Howes, J., Bertuccioli, L. and Chudziak, C. (2009) Review of the Potential for Biofuels in Aviation, Biofuels in aviation E4tech Final Report (for CCC) [online]

http://citeseerx.ist.psu.edu/viewdoc/download;jsessionid=E296A64BF3E834001B8281496DA 49C7D?doi=10.1.1.170.8750\&rep=rep1\&type=pdf (accessed 13 January 2014).

Devianin, S., Markov, V. and Semenov, V. (2007) Plant Oil and Fuels for Diesel Engines, Novoe Slovo, Kharkov.

Dubel, A. (2010) 'Peculiarities and economic efficiency of rape cultivation', Innovative Economics, Vol. 2, No. 2, pp.88-91.

Hemighaus, G., Boval, T., Bosley, C., Organ, R., Lind, J., Brouette, R., Thompson, T., Lynch, J. and Jones, J. (2006) Alternative Jet Fuels: Addendum 1 to Aviation Fuels Technical Review, Chevron Corporation, FTR-3/A1.

Iakovlieva, A. and Boichenko, S. (2012a) 'Cause-effect analysis of jet fuel production and state of environment', Systems and Means of Motor Transport, Monograph No. 3, pp.239-246.

Iakovlieva, A. and Boichenko, S. (2012b) 'Application of biokerosene for improvement of jet engines' ecological characteristics', Aviation and Cosmic Techniques and Technology, Vol. 7 No. 94, pp.60-64.

Iakovlieva, A., Boichenko, S. and Vovk, O. (2013) 'Investigation of properties of biocomponents used in mixture fuels for jet engines - chemmotological view', Systems and Means of Motor Transport, Monograph No. 4, pp.351-356. 
Iakovlieva, A., Vovk, O., Lejda, K., Boichenko, S. and Kuszewski, H. (2014) 'Improvement of technological scheme of fatty acids ethyl esters production for use as jet fuels biocomponents', International Journal of Theoretical and Applied Science, Vol. 11, No. 19, pp.44-50 [online] http://dx.doi.org/10.15863/TAS.2014.11.19.9 (accessed 28 December 2014).

Kaletnik, G. (2008) 'Economic efficiency of biofuel market development in Ukraine', Problems of Science, No. 12, pp.38-43.

Kondili, E. and Kaldellis, J. (2007) 'Biofuel implementation in East Europe: current status and future prospects', Renewable and Sustainable Energy Reviews, No. 11, pp. 2137-2151.

Królczyk, J., Latawiec, A. and Kuboń, M. (2014) 'Sustainable agriculture - the potential to increase wheat and rapeseed yields in Poland', Polish Journal of Environmental Studies, Vol. 23, No. 3, pp.663-672.

Pietak, A. and Radkowski, S. (2011) 'Biofuels - opportunities and challenges', Journal of KONES Powertrain and Transport, Vol. 18, No. 3, pp.25-31.

Proskurina, O. (2011) 'Perspectives of production and application of biofuel in Ukraine', Theoretical and Practical Aspects of Economics and Intellectual Property, No. 1, pp.12-15.

Sagar, P., Kadu, R. and Sarda, H. (2011) 'Use of vegetable oils by transetherification method as CI: engine fuels: a technical review', Journal of Engineering Research and Studies, Vol. 2, No. 3 , pp.19-26.

Wisniewski, G., Kupczyk, A., Rogulska, M. and Lachowicz, T. (2005) 'Development of biofuels market in Poland', Proceedings of the International Conference International Conference 'Eastern Biofuels', Warsaw, Poland, pp.176-184. 